\title{
A new species of Tetragonopterus Cuvier, 1816 (Characiformes, Characidae, Tetragonopterinae) from the upper rio Araguaia, Central Brazil
}

\author{
GABRIEL S. C. SILVA \& RICARDO C. BENINE \\ Laboratório de Biologia e Genética de Peixes, Departamento de Morfologia, IBB-UNESP Campus de Botucatu, Botucatu, SP, 18618- \\ 970, Brazil.E-mail: gabriel_biota@hotmail.com;rbenine@ibb.unesp.br
}

\begin{abstract}
A new characid, Tetragonopterus anostomus, is described from the upper rio Araguaia, Central Brazil. The new species is distinguished from its congeners (T. argenteus, T. carvalhoi, T. chalceus e T. rarus) by traits related to the position of the mouth, number of premaxillary teeth, number of predorsal scales, overall color pattern, and number of gill rakers. A brief discussion on its putative ecomorphological adaptations is provided.
\end{abstract}

Key words: Taxonomy, Neotropical region, Freshwater, Tetragonopterus chalceus

\section{Resumo}

Um novo caracídeo, Tetragonopterus anostomus, é descrito do alto rio Araguaia, região central do Brasil. A nova espécie é distinguida dos seus congeneres (T. argenteus, T. carvalhoi, T. chalceus e T. rarus) por caracteres relacionados à posição da boca, número de dentes do pré-maxilar, número de escamas pré-dorsais, padrão de coloração do corpo e número de rastros branquiais. Uma breve discussão sobre suas pressupostas adaptações ecomorfológicas é fornecida.

\section{Introduction}

The genus Tetragonopterus was proposed by Cuvier in 1816 with the description of Tetragonopterus argenteus. Günther (1864) recognized 32 species in Tetragonopterus, including 12 newly described species, and also proposed the subfamily Tetragonopterinae. In subsequent years, several species of small characids were then described in Tetragonopterus, amounting to over one hundred species. Within the revisionary work of the American characids by Eigenmann $(1917,1918,1921,1927)$ and Eigenmann and Myers (1929), most of its species were re-allocated to available or occasionally newly described genera such as Astyanax, Moenkhausia, and Bryconamericus, restricting Tetragonopterus to only four species, T. chalceus Spix \& Agassiz, 1829, T. argenteus, T. huberi Steindachner, 1909, and T. gibbosus Steindachner, 1877. More recently, Reis (2003) restricted the subfamily Tetragonopterinae to its type-genus and recognized only T. chalceus and T. argenteus as valid species. Both T. huberi and T. gibbosus, along with other 13 nominal species of Tetragonopterus, were placed as species inquirendae by Lima et al. (2003). Tetragonopterus has currently only four valid species, and these can be divided into two groups by the number of predorsal scales: (1) T. argenteus, with 12 to 17 predorsal scales, and (2) T .chalceus, T. rarus (Zarske \& Géry, 2004), and T. carvalhoi Melo, Benine, Mariguela \& Oliveira, 2011, all with seven to nine predorsal scales.

The genus is morphologically defined by presenting a compressed and very deep body, premaxillary teeth in two rows, with the inner tooth-row usually with 5 teeth, a flattened preventral area, bounded laterally by well marked angles, and lateral line complete and strongly bent downward at its anterior portion, as proposed by Eigenmann (1917). Melo et al. (2011), however, in discussing the placement of Moenkhausia rara Zarske and Géry (2006) as a valid species of Tetragonopterus, argued that a branched laterosensory canal of sixth infraorbital (as described by Mirande, 2010), and presence of only three supraneural bones may be synapomorphic for the genus. 